\title{
The Legal Concept of Charity and its Expansion after the Aid/Watch Decision ${ }^{1}$
}

\author{
Fiona Martin \\ University of New South Wales
}

\begin{abstract}
This paper provides the reader with an insight into the legal analysis of the concept of 'charity' and 'charitable purpose'. This discussion is important in light of the 2010 High Court decision in Commissioner of Taxation v Aid/Watch Incorporated. It begins with an overview of the historical development of 'charity' as a legal concept. It then considers how this concept has been interpreted in the context of taxation law and in particular focuses on the arguments for and against a restriction of advocacy and political lobbying by charities. It concludes with an analysis of the Aid/Watch Case and how this may be applied in the future to other charitable entities.
\end{abstract}

\section{Introduction}

This paper provides the reader with an insight into the legal analysis of the concept of 'charity' and 'charitable purpose'. This discussion is important in light of the 2010 High Court decision in Commissioner of Taxation v Aid/Watch Incorporated. ${ }^{2}$ It begins with an overview of the historical development of ‘charity' as a legal concept. It then considers how this concept has been interpreted in the context of taxation law and in particular focuses on the arguments for and against a restriction of advocacy and political lobbying by charities. It concludes with an analysis of the Aid/Watch Case and how this may be applied in the future to other charitable entities.

\section{History of the Common Law Definition of Charity}

The common law definition of charity requires that a charity have a charitable purpose and be for the benefit of the public. ${ }^{3}$ During the $16^{\text {th }}$ century English society saw the role of the Church in charitable work declining and it was increasingly recognized during Elizabeth I's reign that poverty was a national problem. ${ }^{4}$ Around this time there were also a series of

\footnotetext{
${ }^{1}$ This paper was up to date as at 15 April 2011; Draft ATO ruling 2011/D2 was issued on 11 May 2011.

2 [2010] HCA 42.

${ }^{3}$ Commissioners for Special Purposes of Income Tax v Pemsel [1891] AC 531.

${ }^{4}$ William Kitchener Jordan, Philanthropy in England 1480-1660: A Study of the Changing Pattern of English Social Aspirations (Russell Sage Foundation, 1959) Chapters 4-6; Michael Chesterman, Charities, Trusts and Social Welfare (Weidenfeld and Nicolson, 1979)16-24.
} 
events that exacerbated the situation. These included several disastrous harvests, the Spanish war, inflation, a domestic and international economic depression and the plague which killed 14 per cent of the population of London. ${ }^{5}$ These events led to widespread poverty, unemployment and vagrancy. The Elizabethan state became more interventionist and established workhouses to discipline and make productive the poor who could work and also required local parishes to provide for their own poor. ${ }^{6}$ Due to its own lack of funds, the state then turned to the encouragement of private philanthropy to assist. ${ }^{7}$ It did this through three major avenues. First, the Court of Chancery was reinforced as the dominant legal mechanism for enforcing charitable purposes. Secondly, the privileges that the law provided to charitable institutions including remedying many technical defects and ensuring that they did not fail due to uncertainty were confirmed and enhanced. Thirdly, the Statute of Charitable Uses $1601,{ }^{8}$ commonly referred to as the Statute of Elizabeth was enacted. ${ }^{9}$ The aim of this statute was to appoint the bishop of a diocese and the local gentry as commissioners to supervise the administration of most charities and to prevent any misuse of charitable property. ${ }^{10}$ These commissioners were empowered to inquire into the 'abuses breaches of trustes negligences mysimploimentes, not impoloyinge concealinge defraudinge misconvertinge or misgovernmente' of any property given for such 'charitable and godlie uses' as were listed in the statute's Preamble. ${ }^{11}$

It is this statute that is important for the balance of this discussion. The most important feature of this piece of legislation is that it set out a Preamble that comprehensively listed for the first time a range of charitable purposes. This list has been confirmed in subsequent case law as the foundation of the modern legal definition of 'charitable purpose' although it was

\footnotetext{
${ }^{5}$ Myles McGregor-Lowndes, 'Diversions of Charitable Assets: Crimes and Punishments in Australia ' (Paper presented at the National Centre on Philanthropy and the Law: Reforming the Charitable Contribution Deduction 16th Annual Conference, New York, 2004) 4-5; Blake Bromley, '1601 Preamble: The State's Agenda for Charity' (2002) 7 Charity Law and Practice Review 177, 199; Anthony Brundage, The English Poor Laws, 1700-1930 (Palgrave, 2002), 9.

${ }^{6}$ Local parishes were required to provide for assistance for their own poor through the Poor Law Act 1601; For a more detailed discussion refer Blake Bromley, '1601 Preamble: The State's Agenda for Charity' (2002) 7 Charity Law and Practice Review 177, 198-200.

${ }^{7}$ Michael Chesterman, Charities, Trusts and Social Welfare (Weidenfeld and Nicolson, 1979) 19.

${ }^{8} 43$ Eliz. 1, c.4.

${ }^{9}$ Michael Chesterman, Charities, Trusts and Social Welfare (Weidenfeld and Nicolson, 1979)19.

${ }^{10}$ Gareth Jones, History of the Law of Charity 1532-1827 (Cambridge University Press, 1969) Chapter 3; Michael Chesterman, Charities, Trusts and Social Welfare (Weidenfeld and Nicolson, 1979) 16, 24-28.

${ }^{11}$ Michael Chesterman, Charities, Trusts and Social Welfare (Weidenfeld and Nicolson, 1979) 24; Gareth Jones, History of the Law of Charity 1532-1827 (Cambridge University Press, 1969) 225.
} 
never intended as an exhaustive list. ${ }^{12}$ The Preamble sets out the following charitable purposes:

- relief of the aged, impotent and poor;

- maintenance of sick and maimed soldiers and mariners;

- schools and scholars in universities;

- repair of bridges, ports, havens, causeways, churches, sea-banks and highways;

- education and preferment of orphans;

- maintenance of prisons;

- marriages of poor maids;

- $\quad$ aid and help of young tradesmen and handicraftsmen;

- $\quad$ aid and help of persons decayed;

- the relief or redemption of prisoners or captives; and

- the aid or ease of any poor inhabitants concerning payment of fifteens, setting out of soldiers and other taxes. ${ }^{13}$

According to William Kitchener Jordan the statute did not actually create a concept of charitable purposes but rather codified 'a body of law badly wanting classical statement'. ${ }^{14}$

The leading contemporary source of the time considered that the Preamble was an elaborate listing of uses, which would relieve poverty and reduce the local parish's responsibilities under the poor law. It was a list of charities the state wished to encourage. ${ }^{15}$ In effect, the Preamble did not set out a list of areas that were considered altruistically charitable; rather it expressed the state's agenda for charitable giving. ${ }^{16}$ The objects enumerated reflect Elizabethan political, economic and social programs with the government hoping that the wealthy would be encouraged to implement and fund programs in these areas. $^{17}$

\footnotetext{
${ }^{12}$ Michael Chesterman, Charities, Trusts and Social Welfare (Weidenfeld and Nicolson, 1979) 25.

${ }^{13}$ Gareth Jones, History of the Law of Charity 1532-1827 (Cambridge University Press, 1969) 224.

${ }^{14}$ William Kitchener Jordan, Philanthropy in England 1480-1660: A Study of the Changing Pattern of English Social Aspirations (Russell Sage Foundation, 1959)112.

${ }^{15}$ Francis Moore, 'Reading on the Statute of Charitable Uses', in George Duke, The Law of Charitable Uses (Bridgman, 1805).

${ }^{16}$ Blake Bromley, '1601 Preamble: The State's Agenda for Charity' (2002) 7 Charity Law and Practice Review 178.

${ }^{17}$ Graham Moffat, Trusts Law: Text and Materials (Butterworths \& Company Limited, $4^{\text {th }}$ ed, 2004) 884.
} 


\section{The Impact of Income Tax on the interpretation of 'Charity' and 'Charitable'}

In 1799 the British government imposed its first income tax. The legislation was introduced by William Pitt the Younger in his budget of December 1798 to pay for weapons and equipment in preparation for the Napoleonic wars. Pitt's new graduated income tax began at a levy of $2 \mathrm{~d}$ in the pound $(0.8333 \%)$ on incomes over $£ 60$ and increased up to a maximum of 2s (10\%) on incomes of over $£ 200$. Within this statute was an exemption from income tax of any 'corporation, fraternity or society of persons established for charitable purposes only' 18 This exemption appears to have its origins in the 1671 and 1688 land tax exemptions for hospitals and charitable institutions, which was then continued in the income tax context. ${ }^{19}$ In 1816 income tax temporarily ceased, however, it was reintroduced in 1842 with the same exemption. ${ }^{20}$ This exemption from income tax was not popular with everyone and William Gladstone as Chancellor of the Exchequer argued that it should be limited to the relief of hospitals, colleges and almshouses in his budget statement in $1863 .{ }^{21}$ He was however defeated and the exemption for all charities remained. ${ }^{22}$ In his argument Gladstone explained that the original exemption had been warranted at a time when the State made no provision for education or for the poor and that the situation in 1863 was very different and therefore the exemption was no longer needed. ${ }^{23}$

The insertion of this exemption gave rise to the issue of the meaning of 'charitable' in a fiscal context. There was however no judicial consideration of this question for many years due to the fact that until 1874 there was no avenue for an appeal from the income tax commissioners to the courts. ${ }^{24}$ The issue first came to the courts in 1888 in a Scottish case called Baird's Trustees $v$ Lord Advocate ${ }^{25}$ in which the court held that 'charitable' required some element of relief for the poor or deprived. This view was overturned some three years later.

\footnotetext{
${ }^{18}$ Income Tax Act 1799 s5.

${ }^{19}$ John F Avery Jones, 'The Special Commissioners from Trafalgar to Waterloo' in John Tiley (ed), Studies in the History of Tax Law Volume 2 (Hart Publishing, 2007) 3, 14-16. In respect of some hospitals it can be traced back even further as St Bartholomew's Hospital, London was exempt from tax as early as the reign of Edward I (1272-1307) see Michael Gousmett, ‘The Public Benefit Test’ (2006) New Zealand Law Journal 57, 57.

${ }^{20}$ Income Tax Act 1842 s61, No VI, Sch A; s88, Sch C.

${ }^{21}$ (1863) 3 Hansard 170, 200-247; William E Gladstone, The Financial Statements of 1853, 1860-1863. To which are added, A Speech on Tax-Bills, 1861, and on Charities, 1863 (1853, 1860-1863) 370, 426, 461.

${ }^{22}$ Jean Warburton, 'Charity - One Definition for All Tax Purposes in the New Millennium?' [2000] British Tax Review 144, 144.

${ }^{23}$ William E Gladstone, The Financial Statements of 1853, 1860-1863. To which are added, A Speech on TaxBills, 1861, and on Charities, 1863 (1853, 1860-1863) 368.

${ }^{24}$ Michael Chesterman, Charities, Trusts and Social Welfare (Weidenfeld and Nicolson, 1979) 59.

${ }^{25}$ (1888) 15 Sess Cas (4 ${ }^{\text {th }}$ Series) 688.
} 
The watershed decision on the meaning of 'charitable' in an income tax context is considered to be Commissioners for Special Purposes of Income Tax $v$ Pemsel. ${ }^{26}$ This case dealt with a trust of land in England which provided that half of the rents and profits from the land were to go towards the maintenance, support and advancement of missionary establishments of the Protestant Episcopal Church (commonly known as the United Brethren) amongst heathen nations.

Until 1886, the Income Tax Commissioners had granted tax exemptions to the trustees in respect of this trust, under an exemption provision in the Income Tax Act 1842 applying to the rents and profits of lands vested in trustees for 'charitable purposes' as long as they were applied for charitable purposes. In 1886 the Commissioners, under the influence of Gladstone's stricter administration of charities, ${ }^{27}$ withdrew the exemption. The trustees were successful in an appeal to the Court of Appeal and the appeal of the Commissioners to the House of Lords was dismissed by a majority of 4:2.

The House of Lords decision held that for the purposes of exemption from income tax the definition of 'charitable purposes' followed the general law definition which derived from the Preamble to the Statute of Elizabeth. Lord Macnaghten delivered the leading judgment with which Lords Watson and Morris concurred. He stated:

....and those Courts, as they were bound to do, construed the words "charitable uses" in the sense recognised in the Court of Chancery, and in the Statute of Elizabeth, as their proper meaning. I have dwelt for a moment on this point, because it seems to me that there is a disposition to treat the technical meaning of the term "charity" rather as the idiom of a particular Court than as the language of the law of England. And yet of all words in the English language bearing a popular as well as a legal signification I am not sure that there is one which more unmistakeably has a technical meaning in the strictest sense of the term, that is a meaning clear and distinct, peculiar to the law as understood and administered in this country, and not depending upon or coterminous with the popular or vulgar use of the word. ${ }^{28}$

Lord Macnaghten decided that the technical legal meaning of the word 'charitable' was appropriate rather than the ordinary or layperson concept. He argued that the aim of the Statute of Elizabeth was to provide new machinery for the reformation of abuses in regard to charities and that the objects stated in the Preamble were only examples of charitable

\footnotetext{
${ }^{26}$ [1891] AC 531.

${ }^{27}$ Myles McGregor-Lowndes, 'The Australian Definition of Charity' (Paper presented at the National Centre on Philanthropy and the Law, Defining Charity, 14 ${ }^{\text {th }}$ Annual Conference, New York, 24-25 October 2002), 8.

${ }^{28}$ [1891] AC 531, 581-582.
} 
purposes but which had become, by the practice of the Court, an index or chart. ${ }^{29}$ He then traced the history of 'charity' from the Statute of Mortmain in 1736 and the fact that the courts had based their decisions under this enactment on the Preamble and its spirit and intendment. His historical view of the legal definition of 'charitable' was, on this basis, limited to the common law precedents established by the courts since $1736 .^{30}$

The decision confirmed that as long as the purpose of the charity fell within the Preamble or its 'spirit' and a sufficiently large group of the public stood to benefit it was charitable. Lord Macnaghten also formulated a set of four categories of charitable purposes when he said:

"Charity" in its legal sense, comprises four principal divisions: trusts for the relief of poverty; trusts for the advancement of education; trusts for the advancement of religion; and trusts for other purposes beneficial to the community, not falling under any of the preceding heads. ${ }^{31}$

\section{'Charities' as a Concept for the purposes of the Exemption from Income Tax in}

\section{Australia}

The income of charitable institutions is exempt from income tax in Australia under s 50-5 item 1.1 of the Income Tax Assessment Act 1997 (Cth) (ITAA97). ${ }^{32}$ There is no definition of 'charity' in the ITAA97. This is despite the fact that a statutory definition was recommended by the 2001 Report of the Inquiry into the Definition of Charities and Related Organisations. ${ }^{33}$

In 1974 the High Court of Australia confirmed the place of the Preamble to the Statute of Elizabeth in Australian common law in its conclusion that in order for an institution to be charitable it must be:

- Within the spirit and intendment of the Preamble to the Statute of Elizabeth; and

- For the public benefit. ${ }^{34}$

\footnotetext{
${ }^{29}$ Ibid 581.

${ }^{30}$ Ibid 581, 582.

${ }^{31}$ [1891] AC 531, 583.

32 This section was formerly s 23(e) of the Income Tax Assessment Act 1936 (Cth). Charitable funds and institutions are exempt from income tax under ss 50-1 and 50-5 of the Income Tax Assessment Act 1997 (Cth).

${ }^{33}$ Commonwealth of Australia, Ian Sheppard, Robert Fitzgerald and David Gonski, Report of the Inquiry into the Definition of Charities and Related Organisations, June 2001,18; Treasurer's Press Statement 'Final Response to the Charities Definition Inquiry’ 11 May 2004, http://www.treasurer.gov.au/tsr/content/pressreleases/2004/031.asp.

${ }^{34}$ Royal National Agricultural and Industrial Association v Chester [1974] 48 ALJR 304, 305; That this is the law in Australia was originally decided by the Privy Council in Chesterman v Federal Commissioner of Taxation (1925) 37 CLR 317.
} 
This has been reaffirmed more recently by the High Court in the case of Central Bayside General Practice Association Limited $v$ Commissioner of State Revenue of the State of Victoria. ${ }^{35}$

The Australian Taxation Office (ATO) also considers that there are two aspects to the test for an entity to be considered charitable. In its 2005 ruling Income Tax and Fringe Benefits Tax: Charities, the ATO states that for a purpose to fall within the technical legal meaning of 'charitable' it must be beneficial to the community, or deemed to be for the public benefit by legislation applying for that purpose; and within the spirit and intendment of the Statute of Elizabeth, or deemed to be charitable by legislation applying for that purpose. ${ }^{36}$ The ATO also accepts the four categories established in Pemsel's Case as an approach to identifying charitable purposes ${ }^{37}$ being charities for the relief of poverty, advancement of education, advancement of religion and other purposes beneficial to the community.

\section{Charities and Advocacy}

Prior to the High Court decision of Aid/Watch $v$ The Commissioner of Taxation ${ }^{38}$ the common law applying in Australia stated that the public benefit test may be failed where an organisation with a charitable purpose engages in political activity or social advocacy. ${ }^{39}$ This approach is based on the principle that a trust for the attainment of political objects is invalid because the court has no means of judging whether a proposed change in the law will or will not be for the public benefit. ${ }^{40}$

The source of the principle can be found in the comments of Lord Parker in Bowman v Secular Society Ltd in 1917 when he stated:

A trust for the attainment of a political object has always been held invalid, not because it is illegal, for everyone is at liberty to advocate or promote by any lawful means a change in the law, but because the Court has no means of judging whether a proposed change in the law will or will not be for the public benefit, and therefore cannot say that a gift to secure the change is charitable. ${ }^{41}$

\footnotetext{
35 (2006) 228 CLR 168, 178-179; Also Commissioner of Taxation v Word Investments Limited [2008] HCA 55.

${ }^{36}$ Australian Taxation Office, Income Tax and Fringe Benefits Tax: Charities, TR 2005/21, 21 December 2005, [8].

${ }^{37}$ Australian Taxation Office, Income Tax and Fringe Benefits Tax: Charities, TR 2005/21, 21 December 2005, [13].

38 [2010] HCA 42.

${ }^{39}$ Gino Dal Pont, Charity Law in Australia and New Zealand (Oxford University Press, 2000) 203.

${ }^{40}$ Bowman v Secular Society Ltd [1917] AC 406.

${ }^{41}$ Bowman v Secular Society Ltd [1917] AC 406, 442.
} 


\section{Arguments for and against Advocacy of Charities}

There are three main arguments as to why advocacy organisations should be denied charitable status. These are discussed below with the counterarguments.

First, it was stated in Bowman v Secular Society $\operatorname{Ltd}^{42}$ that the acceptance of advocacy organisations who disagree with Government policy would put courts in a position of passing judgement on this policy. However in 1997 Santow J of the New South Wales Supreme Court considered that '[p]ersuasion directed to political change is part and parcel of a democratic society in which ideas and agendas compete for attention and allegiance. ${ }^{43}$ This was not however a case dealing with the income tax exemption.

In the same year a New Zealand judge made the following comments:

Is it really inappropriate for a Judge to recognise an issue as thoroughly worthy of public debate, even though the outcome of that debate might be to lead to a change in the law? After all, it is commonplace for Judges to make suggestions themselves for changes in the law today, whether in judgments or extra-curially...And we do, after all, live in an age which enjoys the supposed benefits of [freedom of thought, conscience, religion and expression]. Should not the benefits be real in all respects, including the law of charities? ${ }^{44}$

More recently, French J observed that the Victorian Women Lawyers’ Association did not engage in disqualifying political activity merely because it made representations and took public positions on matters affecting the position of women generally. ${ }^{45}$

In the twenty first century policy is not developed exclusively by the legislature with the support of the public bureaucracy, nor is this desirable. Governments recognise the important role of advocacy in the health, education and social welfare fields in many ways.

Governments directly fund such bodies, appoint their representatives to advisory bodies, and convene regular meetings between those organisations and relevant Ministers. Even before the Aid/Watch Case it was therefore arguable that this recognition should be extended to the granting of charitable status as these activities are clearly for a public benefit. Furthermore, it

\footnotetext{
42 [1917] AC 406, 442.

${ }^{43}$ Public Trustee v Attorney-General (1997) 42 NSWLR 600, 621.

${ }^{44}$ Re Collier (deceased) [1998] 1 NZLR 81, 89-90 (Hammond J).

${ }^{45}$ Victorian Women Lawyers' Association Inc v Commissioner of Taxation (2008) FCA 983 [149].
} 
is arguable that rather than passing judgment on public policy the courts are being asked to facilitate policy development and public discussion around issues that bear on charitable purposes (such as the relief of poverty) by enabling advocacy organisations to attract financial support from the public. ${ }^{46}$ This activity is for the benefit of the modern community.

A second argument in favour of restricting political activity of charities is that many disadvantaged groups who are the recipients of charitable services are politically controversial and these are the groups that would be involved in advocacy activities. ${ }^{47}$ This in turn would undermine the community support for charities. On the other hand if it is accepted that controversial subject matters are not charitable, groups that aided refugees or racial harmony would not be charities. This would be a great loss to the development of our community and would deny us the opportunity to broaden our perceptions and concepts of welfare and what is charitable.

A third argument for restricting the scope of the advocacy activities of charities is the difficulty in distinguishing between advocacy for charitable purposes and advocacy which is essentially political. ${ }^{48}$ It is certainly arguable that there is already a degree of difficulty in identifying and classifying charitable purposes and that adding further classification strata would merely add to this complexity.

In its submission to the Charities Definition Inquiry the Australian Council of Social Services argued that the appropriate approach is to make a distinction between advocacy for charitable purposes and advocacy with a political end in mind:

The key test of whether these activities are merely political (that is, they aim to increase the political power or influence of the organisation or its members) or charitable (that is, they aim to improve public health, education or social welfare) should be their purpose rather than the nature of the activity itself (for example, whether private lobbying or public advocacy are used as the means to achieve charitable purposes). ${ }^{49}$

\footnotetext{
${ }^{46}$ Charles Rickett ‘Charity and Politics’ (1982) 10 New Zealand Universities Law Review 169, 174.

${ }^{47}$ Michael Chesterman, Charities, Trusts and Social Welfare (Weidenfeld and Nicolson, 1979) 367; Gino Dal Pont, Law of Charity, (Lexisnexis, Australia 2010).

${ }^{48}$ McGovern v Attorney-General [1982] WLR 222, 237 (Slade J).

${ }^{49}$ Australian Council for Social Service Submission to the Inquiry into the Definition of Charities and Related Organisations January 2001 http://www.cdi.gov.au/submissions/134-ACOSS.doc Part 3(3).
} 
The importance of advocacy to charitable organisations is recognised in many of the other submissions to the Charities Definition Inquiry of $2000 .^{50}$ The Central Land Council strongly argued that the ability to advocate on behalf of traditional owners was an important function of charities representing indigenous Australians in view of the history of marginalisation and lack of government resources for these people. ${ }^{51}$

This view seems in keeping with the majority view in the United Kingdom. The Charity Commission for England and Wales has stated that a charity can engage in political activity if 'there is a reasonable expectation that the activity concerned will further the stated purposes of the charity, and so benefit its beneficiaries, to an extent justified by the resources devoted to the activity. ${ }^{, 52}$ The Commission has also stated that charities may comment on public issues, advocate changes in the law, support, oppose, comment on or promote legislation provided that these activities are likely to promote their charitable purposes. ${ }^{53}$ The final aspect of the statement does require a link with the entities charitable purpose and this has always been the case at common law where the courts have said that an ancillary purpose of advocacy is acceptable.

This narrower view that some political activity is only acceptable as long as it is incidental to the main charitable purpose of the organisation was confirmed in Canada by the Supreme Court in Vancouver Society of Immigrant and Visible Minority Women v Minister of National Revenue. ${ }^{54}$ The Court commented that the organisation could retain its charitable status if its conduct of political activities was in the pursuit of its charitable purposes. Its activities were aimed at providing educational benefits such as workshops and seminars for immigrant women. Incidental to this were the objectives of lobbying and fundraising from government

\footnotetext{
${ }^{50}$ For example, Philanthropy Australia Inc Submission to the Inquiry into the Definition of Charities and Related Organisations 19 January 2001 http://www.philanthropy.org.au/pdfs/submission-to-inquiry.pdf Recommendation 2.2; Central Land Council Submission to the Inquiry into the Definition of Charities and Related Organisations 25 January 2001 http://www.cdi.gov.au/submissions/328\%20\%20Central\%20Land\%20Council.doc 4; Australian Council for Social Service Submission to the Inquiry into the Definition of Charities and Related Organisations January 2001 http://www.cdi.gov.au/submissions/134ACOSS.doc Part 3(3).

${ }^{51}$ Central Land Council Submission to the Inquiry into the Definition of Charities and Related Organisations 25 January 2001 http://www.cdi.gov.au/submissions/328\%20-\%20Central\%20Land\%20Council.doc 4.

${ }^{52}$ Charity Commission for England and Wales, Speaking Out: Guidance on Campaigning and Political Activity by Charities, CC9.

${ }^{53}$ E Cairns, Charities: Law and Practice (3 ${ }^{\text {rd }}$ ed, 1996) 29-30.

54 (1999) 99 DTC 5034.
} 
entities for educational support for these women. The organisation's objects specifically stated that it was not to give direct or indirect support to any political party. ${ }^{55}$

Prior to Aid/Watch the ATO confirmed the common law view for Australia that an organisation is not charitable if its purpose is advocating a political party or cause, attempting to change the law or government policy, or propagating a particular point of view. ${ }^{56}$ This was considered to be the case even if the subject matter of the change concerned the relief of poverty, education or religion. ${ }^{57}$ The 2005 ATO ruling does however concede that political or lobbying activities that are incidental to the charitable purpose of an organisation will not affect its charitable status. ${ }^{58}$ A good example of an approach approved by the ATO is the case of Re Inman (deceased) in which Gowans J said:

The general object is...to prevent cruelty to animals...None of the methods set out for the achievement of this object detracts from its character. It is true that one of these methods, viz. procuring such further legislation as may be thought expedient, if taken alone, would be a political object and nothing more. But it is only a method of achieving the main or fundamental object, the prevention of cruelty to animals... ${ }^{59}$

\section{Commissioner of Taxation v Aid/Watch Incorporated}

In 2009 the Full Federal Court of Australia held that an organisation with the charitable purposes of relief of poverty and education was still not charitable on the basis that it was too heavily involved in political activity. ${ }^{60}$ Aid/Watch Incorporated, the subject of this case, has as its purposes research, monitoring and campaigning in relation to the delivery of overseas aid. Its objective is to promote aid programs that are environmentally sound and effectively delivered however it does not provide aid directly. The Court held that one of its main purposes was to attempt to persuade governments (even indirectly) to its point of view, and that this necessarily involved criticism and an attempt to bring about change in government activity and policy. Its political purpose, as demonstrated in its political activity was a separate main purpose and not ancillary to the actual charitable purposes. ${ }^{61}$ The taxpayer was therefore held not to be a charity and appealed from this decision to the High Court of Australia.

\footnotetext{
55 (1999) 99 DTC 5034, [8].

56 Taxation Ruling TR 2005/21, [102].

57 Taxation Ruling TR 2005/21, [107].

58 Taxation Ruling TR 2005/21, [121].

${ }^{59}$ [1965] VR 238, 242.

${ }^{60}$ Commissioner of Taxation v Aid/Watch Incorporated [2009] FCAFC 128.

${ }^{61}$ [2009] FCAFC 128, [37].
} 


\section{High Court Decision}

In a majority judgement with two strong dissenting judgements the High Court held that Aid/Watch was a charity. The High Court stated that the common law as formulated in Bowman v Secular Society did not apply to Australian law. ${ }^{62}$ The High Court found that a purpose of generating public debate about the efficacy of foreign aid directed to the relief of poverty is a charitable purpose. Reliance was placed by the Court on the system of law in Australia, its basis in our Constitution and that it relies upon '...communication between electors and legislators and the officers of the executive, and between electors themselves, on matters of government and politics'. ${ }^{63}$ This Australian context therefore indicated a public benefit aspect to debate and advocacy which is inconsistent with the earlier Bowman $v$ Secular Society principle.

The majority then made some comments indicating a broader approach. The strong suggestion of the court is that within a charity for the advancement of education or religion or relief of poverty encouragement of public debate about changing government policy or government activities will be charitable. The key statements that the Court made are the encouragement of debate. The High Court specifically referred to '...the generation by lawful means of public debate'. ${ }^{64}$

The result of this decision is that charities are allowed an increased ability to carry out campaigning and advocacy activities, rather than just participation in government-led reforms or providing educational information on relevant issues. These activities must however be directed toward purposes which are for the public benefit. Such activities include advocating for improvement in the effectiveness of government policies relating to relief of poverty, advancement of education, advancement of religion or other purposes recognised as beneficial to the community. Furthermore, as discussed below, the activities and objects must not be illegal or contrary to public policy.

It is also likely that representative bodies will have more scope to advocate on behalf of members' interests. This is particularly important for peak bodies that wish to lobby government about systemic issues faced by the sector and in relation to government policy. There is also the possibility that charities are now able to have a sole charitable purpose of

\footnotetext{
${ }^{62}$ [2010] HCA 42 [44]-[48].

63 [2010] HCA 42 [44].

${ }^{64}$ [2010] HCA 42 [47].
} 
bringing about changes in government policy and public opinion in relation to their other charitable purposes. This can be contrasted to the previous legal position where such a purpose was not charitable in its own right.

A further important point to understand is that this decision is consistent with the 2008 decision of the High Court in Commissioner of Taxation $v$ Word Investments Ltd ${ }^{65}$ which demonstrated that the High Court is open to applying the principles of charity law in the context of the values and expectations of modern society.

The two dissenting judgments found that Aid/Watch's purpose was not charitable. This conclusion was based on the view that the entity's objects and activities involved the promotion of particular points of view rather than a more neutral approach to the generation of public debate.

\section{What is not within Aid/Watch}

It has been a long held requirement of the common law that activities and purposes of charities that offend public policy principles are not charitable. ${ }^{66}$ An entity’s purpose is not beneficial if its aims are contrary to public policy, ${ }^{67}$ unlawful or for a lawful purpose that is to be carried out by unlawful means. ${ }^{68}$

The types of purposes that are envisaged are illegal acts, purposes or objects which threaten national security such as terrorist activity, religious purposes that place its adherents at risk or which are illegal in some way, education for illegal or harmful purposes or to encourage illegal activities and discrimination against particular classes of people which goes beyond what is allowed by law. ${ }^{69}$ The Aid/Watch decision does not change this principle. It is certainly arguable that in most cases these restrictions are not overly intrusive on a charity's purposes and activities. However some charities suggest that there is the exception where charities engage in civil disobedience or where the law is unclear or it conflicts with a moral perspective. $^{70}$

\footnotetext{
65 [2008] HCA 55.

${ }^{66}$ Perpetual Trustee Co (Ltd) v Robins (1967) 85 WN (Pt. 1) (NSW) 403, 411; Gino Dal Pont, Law of Charity, (Lexisnexis, Australia 2010) 72-75.

${ }^{67}$ Perpetual Trustee Co (Ltd) v Robins (1967) 85 WN (Pt. 1) (NSW) 403, 411; See also Thrupp v. Collett (No 1) (1858) 53 ER 844; Re MacDuff; MacDuff v MacDuff [1895] 2 Ch 451; Re Pieper (deceased ); The Trustees Executors \& Agency Co. Ltd v Attorney-General (Vic) [1951] VLR 42.

${ }^{68}$ Auckland Medical Aid Trust v Commissioner of Inland Revenue [1979] 1 NZLR 382, 395.

${ }^{69}$ Gino Dal Pont, Law of Charity, (Lexisnexis, Australia 2010) 72-75.

${ }^{70}$ Changemakers Australia, Charity Law Reform Project (Esther Abram, 2011) 30.
} 
It is also unclear just how far the Aid/Watch decision extends. What does the Court mean by the generation of public debate in the context of charities in the first three categories and second, when does it apply to charities that fall within the fourth charitable head, 'other purposes beneficial to the community’.

In other words can a religion or a school or a charity that is working to relieve poverty such as Aid/Watch advocate a point of view to such an extent that they endorse a particular political party as having in its opinion, the best policy? The idea of debate implies a weighing up or balancing of information and ideas, the talking about something at length and in detail, especially as part of a formal exchange of opinion. Perhaps this is as far as the decision extends and supporting one political party over another goes too far but the situation is not entirely clear.

Furthermore, is it acceptable for charities that fall within other purposes that are beneficial to the community such as those that fight to protect the environment or for animal rights to engage in advocacy or lobbying to the same extent as charities that fall within the first three categories? Is there a difference and if so where do we draw the line? Advocating a particular point of view and supporting a particular political party's policy is often extremely attractive to organisations that are engaged in environmental activism or protection of human or animal rights. It is also important to other organisations such as those that favour relaxing gun control and anti-abortion groups. Is there a requirement in the concept of 'debate' that both sides of the argument are represented in some way?

\section{Conclusion}

The ATO is now engaged in the process of drafting a new ruling to replace the 2005 ruling referred to earlier in this discussion. ${ }^{71}$ The initial ruling will be released in draft form with a chance for members of the not-for-profit sector and their advisors to comment. It is however expected that the ATO will seek to narrow the application of the Aid/Watch decision. ${ }^{72}$ It is therefore important that members of the charity and not-for-profit sector respond to the draft ruling with strong and cohesive submissions. These submissions should emphasise the decision of the High Court in Aid/Watch that the Bowman $v$ Secular Society principle no longer applies in Australia and that public debate is a benefit to the community and an important aspect of our legal and democratic system.

\footnotetext{
${ }^{71}$ Changemakers Australia, Charity Law Reform Project (Esther Abram, 2011) 31.

${ }^{72}$ Changemakers Australia, Charity Law Reform Project (Esther Abram, 2011) 31.
} 